\title{
LINDENS: A program for lineament length and density analysis ${ }^{\text {th }}$
}

\author{
Antonio M. Casas $^{\mathrm{a}, *}$, Angel L. Cortés ${ }^{\mathrm{b}}$, Adolfo Maestro ${ }^{\mathrm{a}}$, M. \\ Asunción Soriano $^{\mathrm{a}}$, Andres Riaguas ${ }^{\mathrm{c}}$, Javier Bernal ${ }^{\mathrm{d}}$ \\ ${ }^{a}$ Departamento de Geología, Facultad de Ciencias, Universidad de Zaragoza, 50009, Zaragoza, Spain \\ ${ }^{\mathrm{b}}$ Departamento de Didáctica de las Ciencias Experimentales, Universidad de Zaragoza, 50009, Zaragoza, Spain \\ ${ }^{\mathrm{c}}$ Departamento de Matemática Aplicada, Universidad de Zaragoza, 50009, Zaragoza, Spain \\ ${ }^{\mathrm{d}}$ National Institute of Standards and Technology, Gaithersburg, Maryland, USA
}

Received 2 May 1999; received in revised form 30 November 1999; accepted 30 November 1999

\begin{abstract}
Analysis of lineaments from satellite images normally includes the determination of their orientation and density. The spatial variation in the orientation and/or number of lineaments must be obtained by means of a network of cells, the lineaments included in each cell being analysed separately. The program presented in this work, LINDENS, allows the density of lineaments (number of lineaments per $\mathrm{km}^{2}$ and length of lineaments per $\mathrm{km}^{2}$ ) to be estimated. It also provides a tool for classifying the lineaments contained in different cells, so that their orientation can be represented in frequency histograms and/or rose diagrams. The input file must contain the planar coordinates of the beginning and end of each lineament. The density analysis is done by creating a network of square cells, and counting the number of lineaments that are contained within each cell, that have one of their ends within the cell or that cross-cut the cell boundary. The lengths of lineaments are then calculated. To obtain a representative density map the cell size must be fixed according to: (1) the average lineament length; (2) the distance between the lineaments; and (3) the boundaries of zones with low densities due to lithology or outcrop features. An example from the Neogene Duero Basin (Northern Spain) is provided to test the reliability of the density maps obtained with different cell sizes. (C) 2000 Elsevier Science Ltd. All rights reserved.
\end{abstract}

Keywords: Lineament; Density map; Directional analysis; Satellite images; Duero Basin; Fortran

\section{Introduction}

Satellite lineaments are linear features on the Earth's surface, usually related to the sub-surface

\footnotetext{
* Code available at http://www.iamg.org/CGEditor/ index.htm

* Corresponding author. Fax: + 34-76-761-088.

E-mail address: acasas@posta.unizar.es (A.M. Casas).
}

phenomena. In areas of gently folded or horizontal strata, lineaments are related to fractures and faults, and their orientation and number give an idea of the fracture pattern of rocks (Arlegui and Soriano, 1998; Cortés et al., 1998). Because satellite images can be obtained using varying wavelength intervals of the electromagnetic spectrum, they have the ability of producing better information than conventional aerial photographs. The tracing of lineaments can be done (1) on a print copy or (2) directly on the 
computer screen by means of standard graphics programs. In the first approach, lines must be digitised for creating a data file, preferably in a vectorial format. In the second approach, computer programs directly provide the coordinates of the beginning and end of each straight line.

Analysis of lineaments from satellite images is usually accomplished by automatic programs able to obtain the coordinates of the beginning and end of each lineament, and in some instances their orientation and length. A simple determination of density of lineaments can be made from a file with such data by creating a network of square cells (usually bounded by vertical and horizontal lines) and selecting lineaments that begin or end within the horizontal and vertical lines bounding each cell (Cortés et al., 1998). Analysis of lineament density consists of either counting the number of lineaments contained in each cell or calculating the lengths of the lines contained within the cell limits. The result is then divided by the area of the cell, taking into account that some areas within the cell may not be considered (for example, an outcrop of rocks of different age).

The second method (calculating lengths of lines) more accurately gives the image of lineament density, since the total length per unit of area then only depends on the lines or segments of lines completely contained within the cell. If a lineament begins within the cell, but only a few points are within it, then it will be added as a significant quantity when considering the number of lineaments, whereas its influence on the total will be negligible when considering the length of lines. Finally, the results can be presented by a contour map of density of lineaments or by colouring cells according to the density in each one (Cortés et al., 1998; Arlegui and Soriano, 1998).

Although the calculation of the number of lineaments beginning or ending within each cell can be
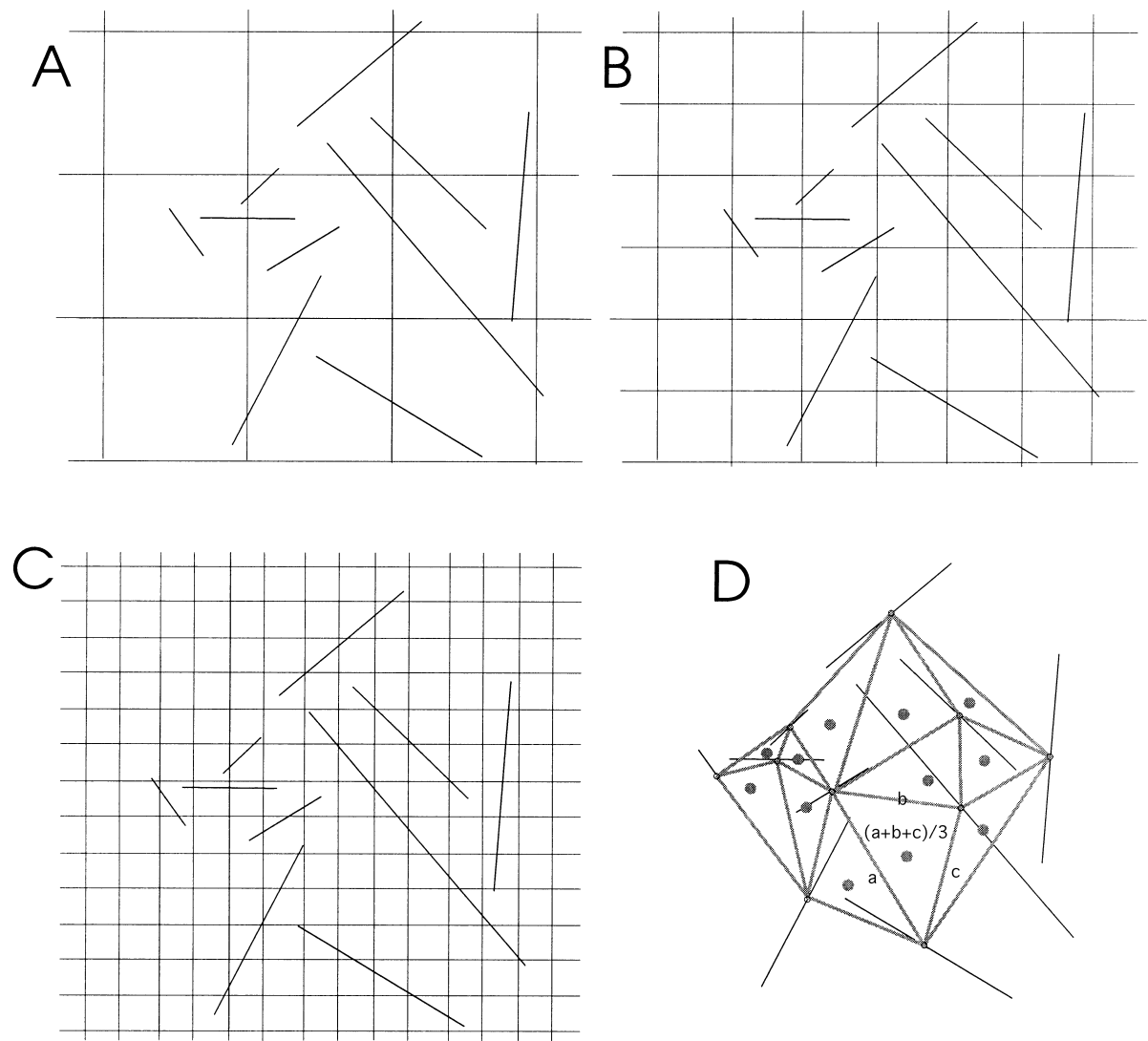

Fig. 1. Example showing influence of cell size in density map. In grids shown in $A$ and $B$, no barren cells appear in space between lineaments. In grid $C$, closely spaced lineaments are separated by barren cells and density map will not be representative. Minimum cell size can be calculated by means of Delauney triangulation $(D)$. Each lineament is represented by its central point, used for calculating spacing between lineaments. Mean distance is defined as arithmetic mean of length of sides of each triangle $([a+b+c] / 3)$. 
accomplished with a simple calculation sheet (or program), from the data file, an automatic program is necessary to count the number of lineaments traversing each cell or the lengths of the lines within the cell. The program presented here (designed in FORTRAN 77 for Macintosh and PC) allows this kind of calculation by means of a simple geometrical algorithm. A discussion about the best-fit cell size is also presented, with an example of directional and density analysis of recent fracturing in the horizontal strata of the Neogene Duero Basin (Northern Spain). The methods described and the program presented in this work are not only applicable to satellite lineaments, but also to faults and fractures obtained from the analysis of aerial photographs in conventional or electronic format.

\section{The problem of lineament analysis}

In structural geology, satellite images help to identify materials and their structure, independent of their age and kind of deformation (Jutz and Chorowicz, 1993; Drury and Berhe, 1993; Nash et al., 1996). These images are especially useful for recognising linear structures and lineaments, defined by Sabins (1987) as straight linear features, presumably expressing a subsurface phenomenon, that differ distinctly from the patterns of adjacent features. The surface features showing a lineament may be geomorphic (caused by relief) or tonal (caused by contrast differences). The genetic meaning of lineaments could be widely discussed although these discontinuities include both landscape morphologic elements and several tectonic processes (Scanvic, 1975; Chukwu and Norwan, 1977). In folded and/or thrusted areas, lineaments can correspond to several kinds of structures or bed contours (Sanderson and Chinn, 1989; Heddi and Eastaff, 1995), whereas in flat-lying beds, linear features are usually linked to fracturing (Arlegui and Soriano, 1996, 1998).

Identification of lineaments is conditioned by the outcrop conditions of studied rocks. The presence of both a dense vegetation canopy and recent non-consolidated deposits (fluvial terraces, pediments or alluvial sediments) prevents the identification of lineaments (Cortés et al., 1998). Determination of linear patterns is also difficult in zones with intensive-farming use and human landscape transformations. Existence of large zones with information voids due to vegetation or lithology complicates the calculation of density values. These data uncertainties can make it useless to perform the automatic drawing of density contours.

A network with square cells must be designed to calculate the number of lineaments and lineament lengths within each cell. Density values can be spatially distrib- uted as points on a map. The graphical display of equal-density areas can be done either with grey-level coding of grid squares or with contour maps. Contour maps show spatial variations in the parameter analysed. However, when the grid spacing is small several problems may arise: (1) the difference between the values of adjacent squares may be very high, so that a large number of lines must be used, many of them corresponding to non-existing values; (2) the number of contour lines may be large, and visual interpretation of maps is more difficult than with coloured squares.

Another problem is the determination of the most representative square size for the creation of density maps. Distances between lineaments must condition the critical size of the appropriate grid (Fig. 1). To determine this distance, we used the Delauney triangulation method (Preparata and Shamos, 1985). We computed a Delauney triangulation for the set of midpoints of the lineaments and then the mean distance for each triangle in the triangulation. The mean distance for a triangle is the arithmetic mean of the lengths of its three sides (Fig. 1). The best grid size, the one that produces the most accuracy, is then the smallest mean distance possible. It should be noted here that barren cells (zero density values) between closely spaced lineaments are artifacts that should be avoided. Since the mean distances may change in different zones of the studied area, and the same grid must be used throughout the area, an intermediate grid size may produce the best global results (see next).

\section{Program design}

\subsection{Geometric algorithm}

Once a network of square cells is defined, five types of relationship between the straight lines representing the lineaments and the cell contours can be identified (Fig. 2A). Let $x_{1}, y_{1}$ and $x_{2}, y_{2}$ be the beginning and end of the lineament, respectively; $x_{\text {lef }}$ and $x_{\text {rig }}$ the $x$ coordinates of the left and right vertical lines limiting the cell; $y_{\text {up }}$ and $y_{\text {low }}$ the $y$-coordinates of the upper and lower limits of the cell (Fig. 2B). The five kinds of relationships are the following:

1. Lines outside the square cell (marked as 1 in Fig. 2A), with their $x$ - and/or $y$-coordinates of both their endpoints larger or smaller than the upper and lower bounds of the cell, respectively (see conditions in Table 1).

2. Lines completely contained within the cell (marked as 2 in Fig. 2A).

3. Lines beginning and ending outside of the cell, but intersecting the interior of the cell (marked as 3 in Fig. 2A). 

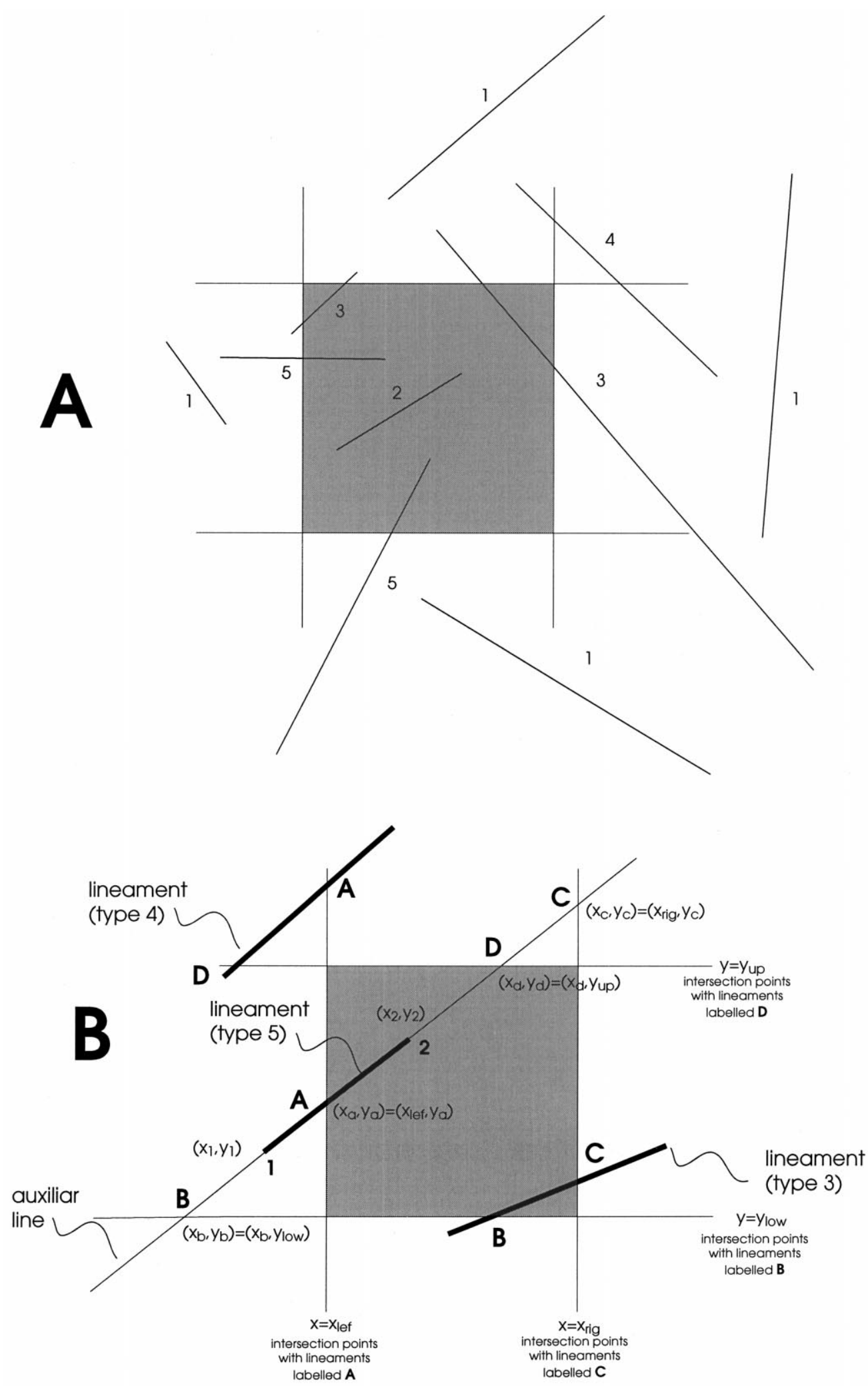

Fig. 2. A. Types of lineaments according to geometric relationship with cell walls (see text and Table 1 for explanation). B. Definition of in-plane coordinates of lineaments and lines bounding each cell used in this work. 
4. Lines outside the cell, but with either the $x$ - or the $y$-coordinate of each of its endpoints within the cell bounds (marked as 4 in Fig. 2A); these lines are not comprised within type 1 .

5. Lines with exactly one of their endpoints within the cell (marked as 5 in Fig. 2A).

The conditions for lineaments to be counted within the cell are then expressed as a function of the type of lineament (Table 1). Types 1 and 2 are the first to be classified, then avoiding the rest of the calculations and this requires no line intersection calculations. For the other three types, the intersections of the lineaments with the four lines delimiting the square cell $(A$, $B, C, D)$ must be calculated (see Fig. 2B).

The measured length of each lineament also varies according to the types defined. For type 2, all the lineament length is considered. For type 3, the measured length is the one between the two intersections of the lineament with the cell boundary. For type 5 , the measured length goes from the extremity of the lineament contained in the cell to the intersection of the lineament with the cell boundary.

The program first computes each cell through two nested loops, and then opens the data file, reading the coordinates of each lineament and classifying it according to the types described above, with two matrix variables counting the length and number of lineaments in each cell. Once the whole data file has been read and the data file is closed, the next cell takes on the process. Filter corrections are applied for near vertical or

Table 1

Analytical expressions showing conditions for classification of geometrical relationships between lines and cells ${ }^{\mathrm{a}}$

Type 1
or
or
or
Line length 0
Type 2
$\quad x_{\text {lef }}<x_{1}<x_{\text {rig }}$ and $y_{\text {low }}<y_{1}<y_{\text {up }}$ and $x_{\text {lef }}<x_{2}<x_{\text {rig }}$ and $y_{\text {low }}<y_{2}<y_{\text {up }}$
Line length $\left[\left(x_{1}-x_{2}\right)^{2}+\left(y_{1}-y_{2}\right)^{2}\right]^{1 / 2}$

Type 3

$y_{\mathrm{a}}<y_{\text {low }}$ and $y_{\mathrm{c}}>y_{\text {up }}$

$y_{\mathrm{c}}<y_{\text {low }}$ and $y_{\mathrm{a}}>y_{\text {up }}$

$x_{\mathrm{b}}<x_{\text {lef }}$ and $x_{\mathrm{d}}>x_{\text {rig }}$

$x_{\mathrm{d}}<x_{\text {lef }}$ and $x_{\mathrm{b}}>x_{\text {rig }}$

$y_{\mathrm{a}}<y_{\text {low }}$ and $x_{\mathrm{d}}>x_{\text {rig }}$

$y_{\mathrm{a}}>y_{\text {up }}$ and $x_{\mathrm{b}}>x_{\text {rig }}$

$y_{\mathrm{c}}<y_{\text {low }}$ and $x_{\mathrm{d}}<x_{\mathrm{lef}}$

$x_{\mathrm{b}}<x_{\text {lef }}$ and $y_{\mathrm{c}}>y_{\text {up }}$

Type 4

or

or

or

Line length 0

Type 5

or (excluding)

for $x_{\text {lef }}<x_{1}<x_{x \text { rig }}$ and $y_{\text {low }}>y_{1}>y_{\text {up }}$

$\left[x_{2}>x_{\mathrm{a}}>x_{1}\right.$ or $\left.x_{1}>x_{\mathrm{a}}>x_{2}\right]$ and $\left[y_{2}>y_{\mathrm{a}}>y_{1}\right.$ or $\left.y_{1}>y_{\mathrm{a}}>y_{2}\right]$

$\left[x_{2}>x_{\mathrm{b}}>x_{1}\right.$ or $\left.x_{1}>x_{\mathrm{b}}>x_{2}\right]$ and $\left[y_{2}>y_{\mathrm{b}}>y_{1}\right.$ or $\left.y_{1}>y_{\mathrm{b}}>y_{2}\right]$

$\left[x_{2}>x_{\mathrm{c}}>x_{1}\right.$ or $\left.x_{1}>x_{\mathrm{c}}>x_{2}\right]$ and $\left[y_{2}>y_{\mathrm{c}}>y_{1}\right.$ or $\left.y_{1}>y_{\mathrm{c}}>y_{2}\right]$

$\left[x_{2}>x_{\mathrm{d}}>x_{1}\right.$ or $\left.x_{1}>x_{\mathrm{d}}>x_{2}\right]$ and $\left[y_{2}>y_{\mathrm{d}}>y_{1}\right.$ or $\left.y_{1}>y_{\mathrm{d}}>y_{2}\right]$

Analogous conditions for $x_{\text {lef }}<x_{2}<x_{x \text { rig }}$ and $y_{\text {low }}>y_{2}>y_{\text {up }}$

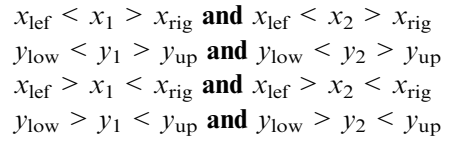

Line length BD

Line length $\mathrm{BD}$

Line length AC

Line length $\mathrm{AC}$

Line length $\mathrm{BC}$

Line length $C D$

Line length $\mathrm{AB}$

Line length $\mathrm{AC}$

$$
\begin{aligned}
& y_{\mathrm{a}}<y_{\text {low }}>y_{\mathrm{c}} \\
& y_{\mathrm{a}}>y_{\text {up }}<y_{\mathrm{c}} \\
& x_{\mathrm{b}}<x_{\text {lef }}>x_{\mathrm{d}} \\
& x_{\mathrm{b}}>x_{\text {rig }}<x_{\mathrm{d}}
\end{aligned}
$$

\footnotetext{
${ }^{\mathrm{a}}$ For graphic expression of different types, see Fig. 2A.
}

$x_{\text {lef }}<x_{1}<x_{x \text { rig }}$ and $y_{\text {low }}>y_{1}>y_{\text {up }}$ $x_{\text {lef }}<x_{2}<x_{x \text { rig }}$ and $y_{\text {low }}>y_{2}>y_{\text {up }}$

Line length $\left[\left(x_{1}-x_{\mathrm{a}}\right)^{2}+\left(y_{1}-y_{\mathrm{a}}\right)^{2}\right]^{1 / 2}$

Line length $\left[\left(x_{1}-x_{\mathrm{b}}\right)^{2}+\left(y_{1}-y_{\mathrm{b}}\right)^{2}\right]^{1 / 2}$

Line length $\left[\left(x_{1}-x_{\mathrm{c}}\right)^{2}+\left(y_{1}-y_{\mathrm{c}}\right)^{2}\right]^{1 / 2}$

Line length $\left[\left(x_{1}-x_{\mathrm{d}}\right)^{2}+\left(y_{1}-y_{\mathrm{d}}\right)^{2}\right]^{1 / 2}$ 


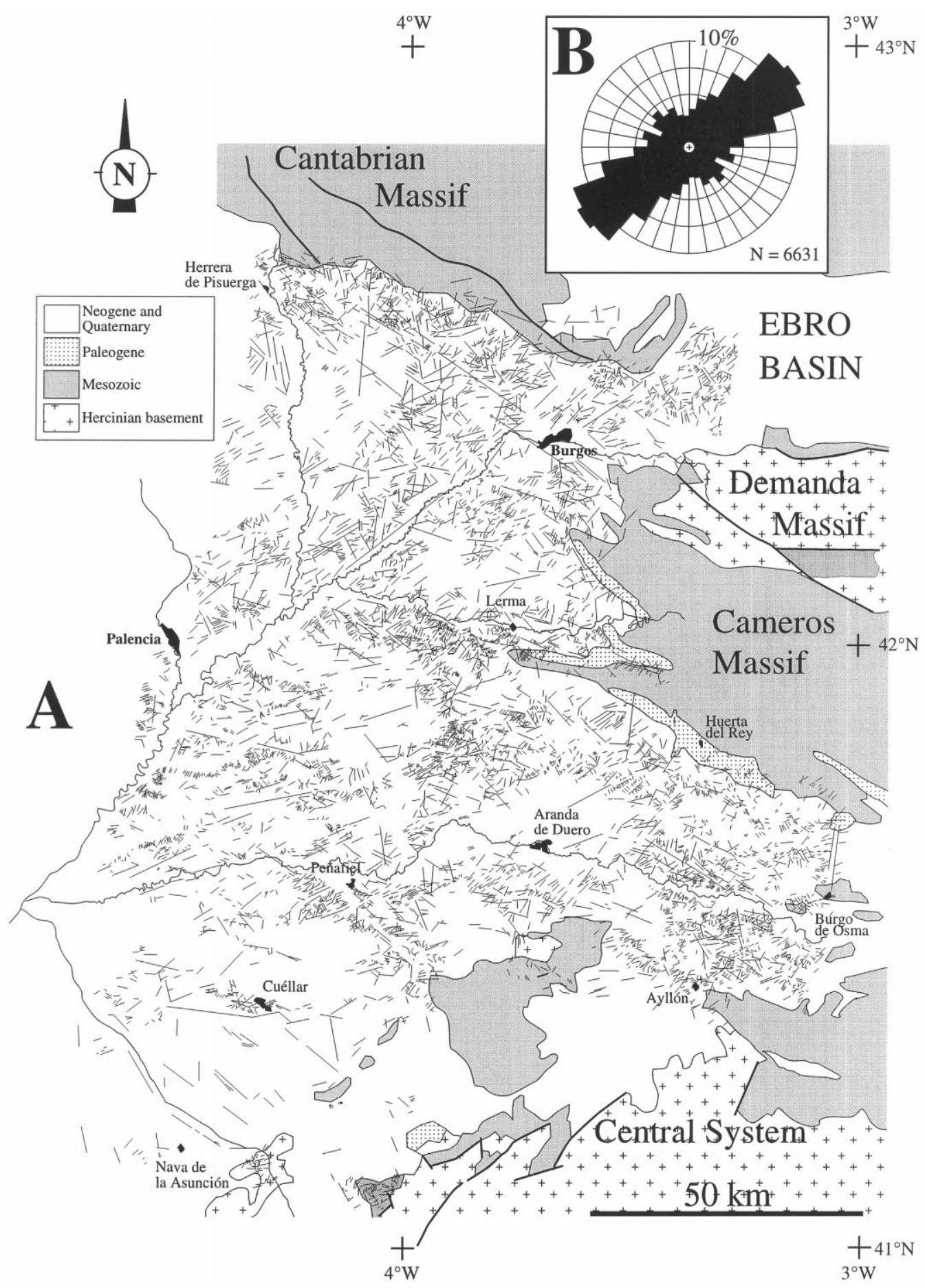

Fig. 3. A. Satellite lineament map of example presented, at Eastern Duero Basin. B. Orientation frequency for all data summarized by rose diagram. 
horizontal lineaments, since their intersections with the two sub-parallel cell boundary lines may be out of range, and only their intersections with the two nearperpendicular cell boundary lines are considered. The program works whatever the order of the beginning and end of the lineament, that is the $x$ - and $y$-coordinates of the beginning may be larger or smaller than the corresponding coordinates of the end of the line. The computing time may be long when a large number of data and a large area are involved.

\subsection{Input data format}

The standard input must contain the coordinates of the initial and final point of each lineament (four numbers, with a maximum of six digits each, including points), separated by tabs or spaces. The data corresponding to different lineaments are arranged in different lines. The program presented here creates files for directional analysis of lineaments passing through each cell (e.g. rose diagrams, etc.). The azimuth of each line is obtained from the variable $A L F A T A N$ in the program, since the angle with the north (when the vertical lines bounding the cells coincide with the north-south direction) is 90-ALFATAN. Directional analysis of these data can be carried out either by means of standard statistics programs (frequency histograms) or programs for geological data (rose diagrams).

The user must introduce, during the running of the program, the rest of the parameters corresponding to the analysis performed: (i) the names of files for data input and output; (ii) the initials (maximum three characters) of the files for directional analysis of lineaments within the cell (the rest of the characters are the row and column of the corresponding cell); (iii) the number of rows and columns; (iv) the width of each cell; (v) the coordinates of the origin (not necessarily 0,0 ); and (vi) the conversion (scale) factor, in its present form metres/pixel.

\subsection{Output data format}

The output file indicates in the first place the parameters used to analyse the data and the names of the input and output files. Following these lines the results are written in seven column, each row corresponding to the data contained within one cell. The first and second columns indicate the position of the cell; the third and fourth columns correspond to the $(x, y)$ coordinates of the centre of the cell; the fifth column indicates the number of lineaments contained within the cell; finally, the sixth and seventh columns indicate the length of lineaments (in pixels and metres, if the conversion factor has been entered) contained within the cell. Directional data $(A L F A T A N)$ do not appear in the general output file. The format of the output file allows one to quickly obtain the density of lineaments (in terms of the number or length of the lineaments per square unit in each cell) and also an easy conversion to programs for tracing contours indicating this density of lineaments.

\section{Case study}

In the eastern part of the Duero Basin (Northern Spain), 6631 lineaments have been identified from the study of satellite images (Fig. 3A). Most of the outcropping rocks are sandstones, shales, and limestones of Neogene age and are sub-horizontal throughout the area. Lineaments present a heterogeneous spatial distribution. Their number is very high west of Sierra de Lerma, the Burgo de Osma-Ayllón sector, and close to
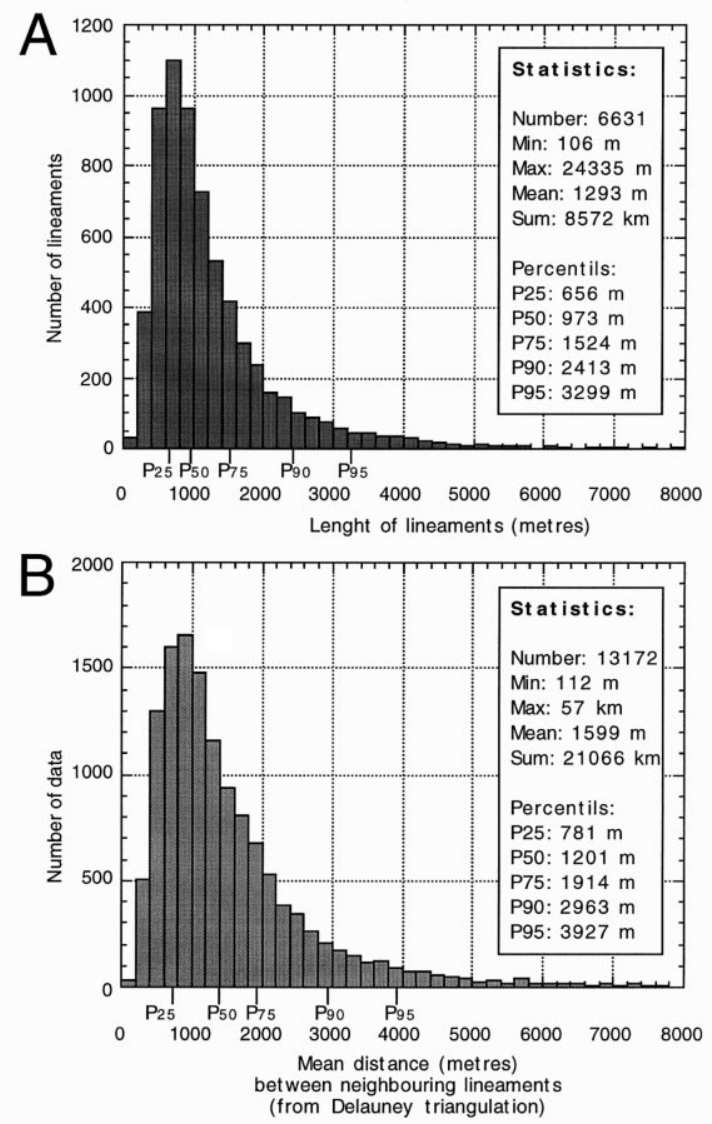

Fig. 4. A. Histogram and statistics of lineaments drawn from satellite image in Eastern Duero Basin. B. Histogram and statistics of mean distance between lineaments, according to method shown in Fig. 1D. 
the southern border of the Cantabrian Mountains. In the proximity of major rivers, the number of lineaments is low, probably due to the presence of quaternary terraces in which lineaments cannot be identified. Similar conditions occur near Aranda de Duero and Cuéllar, where the presence of important landscape transformations associated with intensive-farming precludes the identification of lineaments.

A quantitative analysis of lineaments was carried out to determine the size and orientation patterns of lineament sets at the regional scale. The results of the directional analysis do not show significant differences in the distribution of orientations (Fig. 3B): the main lineament direction is NE-SW. The minimum and maximum recorded lengths are 105 and $24,335 \mathrm{~m}$, respectively. The histogram of lineament lengths shows a log-normal distribution, with a mode about 600-650 m (Fig. 4A). The mean distance between neighbouring lineaments was calculated by means of Delauney triangulation, as discussed above. The mean distances for

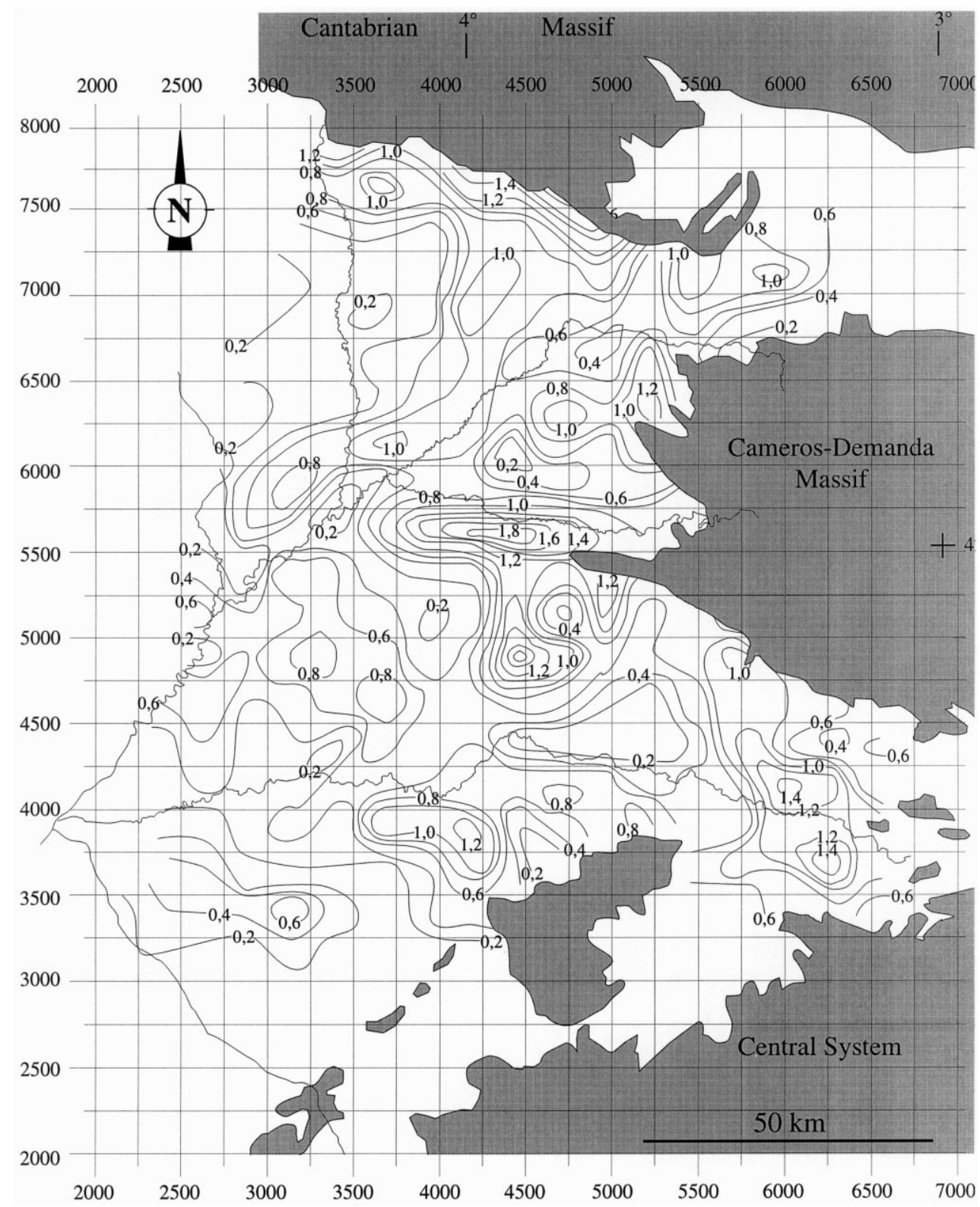

Fig. 5. Density map of lineament length per $\mathrm{km}^{2}$ using $250 \times 250$ pixels $(7.5 \times 7.5 \mathrm{~km})$ grid. 
all the triangles show a log-normal distribution with a mode of $1000 \mathrm{~m}, P_{90}=2963 \mathrm{~m}$ and $P_{95}=3927 \mathrm{~m}$ (Fig. 4B).

The spatial variation in the number (and length) of lineaments was done represented by a network of square cells, taking into account the lengths of lineaments (per $\mathrm{km}^{2}$ ) included in each cell. Lineament density rates were obtained by the LINDENS program described previously. According to the criteria described before and the distance histogram (Fig. 4B) the best results should have been obtained for grids with cell sizes comprised between $3 \times 3$ and $4 \times 4 \mathrm{~km}$. Besides these theoretical values, higher and lower values (Figs. 5-7) were used to determine the best picture of lineament density.

The best results were obtained for grids of $250 \times$ 250 pixels $(7.5 \times 7.5 \mathrm{~km}$, Fig. 5) and $125 \times 125$ pixels $(3.7 \times 3.7 \mathrm{~km}$, Fig. 6). Grids larger than $7.5 \times 7.5 \mathrm{~km}$ did not allow for the determination of the locations of the maxima with geological meaning, mainly located west of the Cameros-Demanda Massif, along the prolongation of the main anticlines below the Neogene of the Duero Basin, and at the southern border of the Cantabrian Mountains. For the $3.7 \times$ $3.7 \mathrm{~km}$ grid representation of values, a grey-level code was chosen, because neighbour cells show strongly

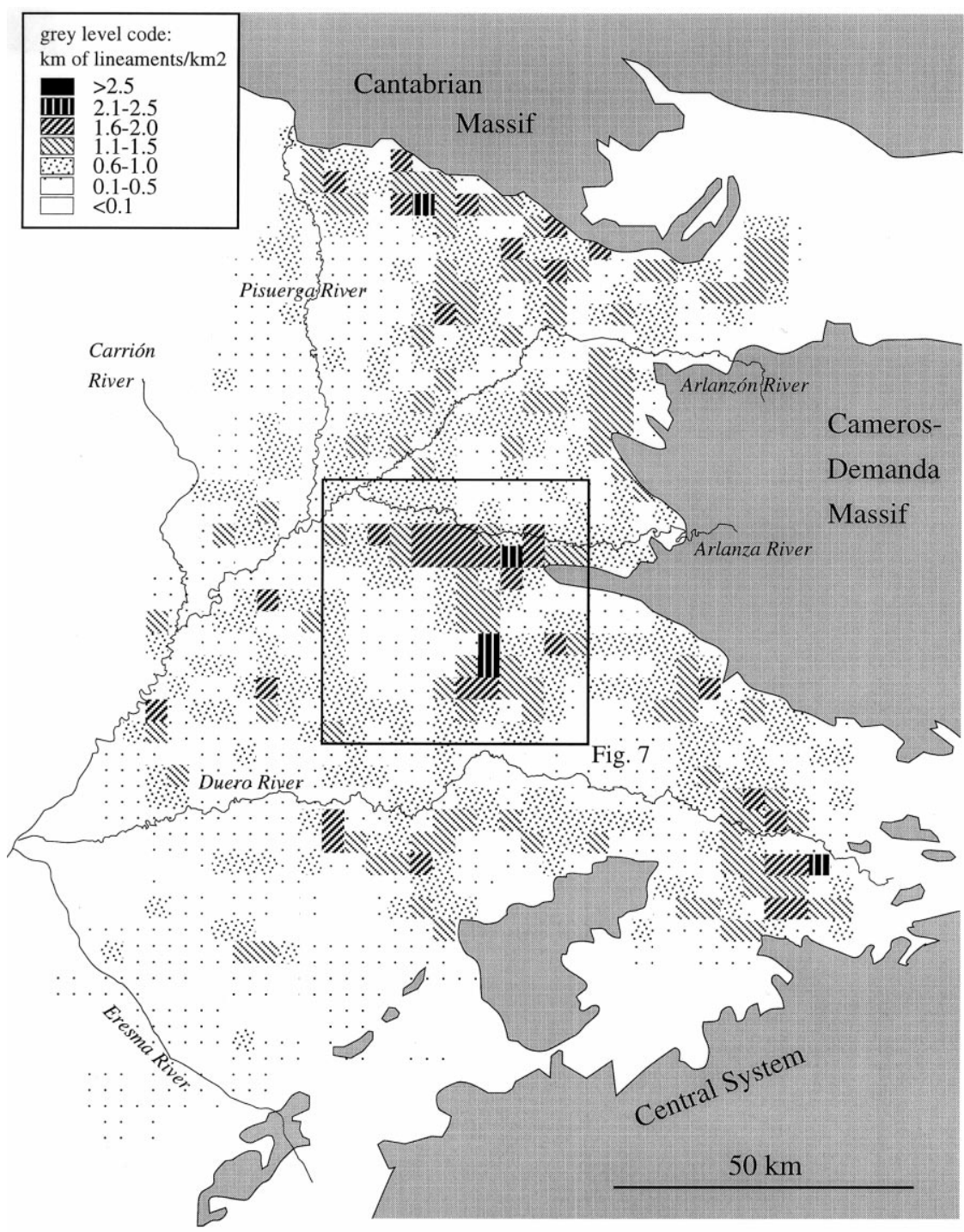

Fig. 6. Density map of lineament length per $\mathrm{km}^{2}$ using $125 \times 125$ pixels $(3.7 \times 3.7 \mathrm{~km})$ grid. 


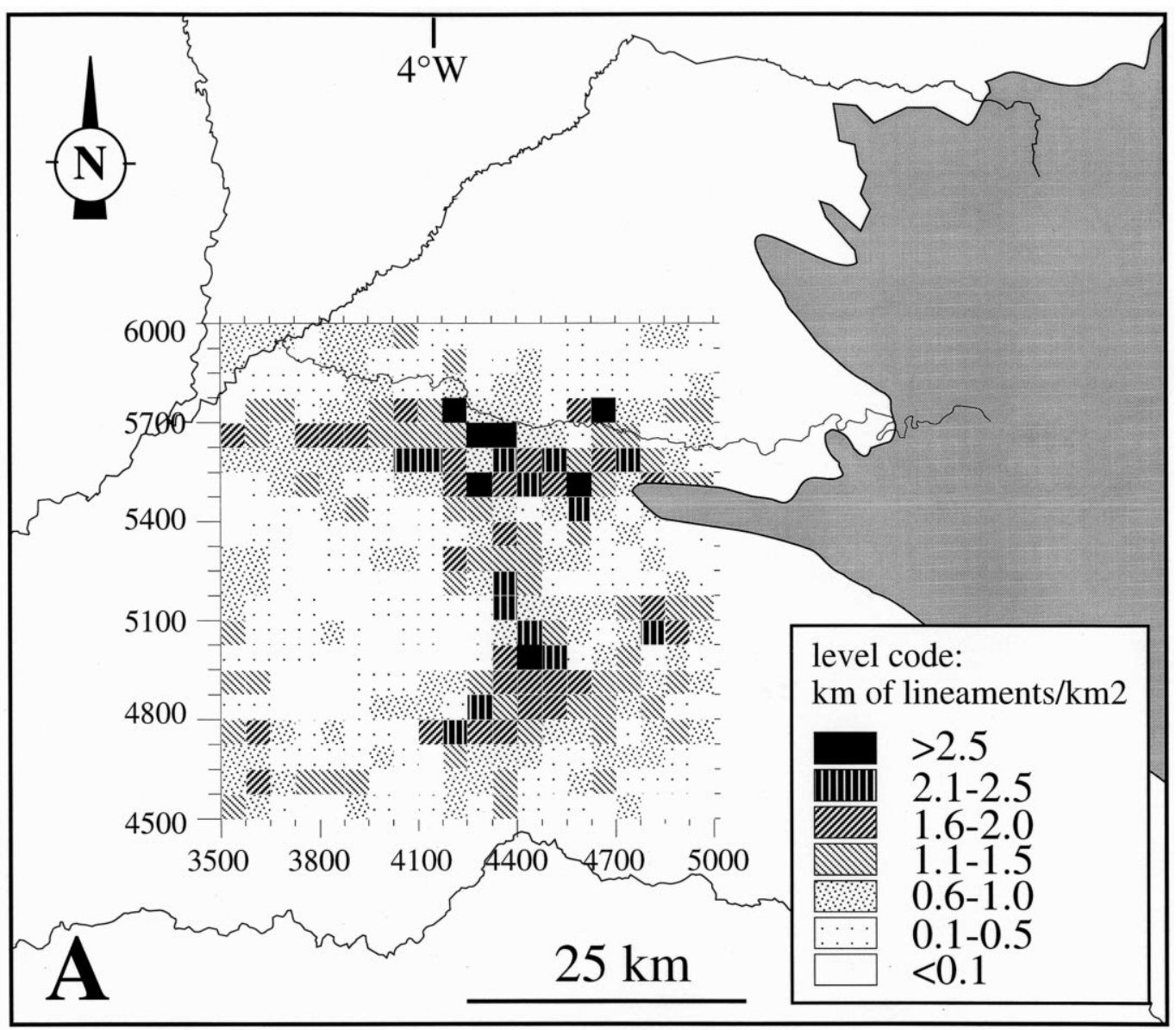

Fig. 7. A. Density map of lineament length per $\mathrm{km}^{2}$ using $75 \times 75$ pixels $(2.3 \times 2.3 \mathrm{~km})$ grid. B. Density map of lineament length per $\mathrm{km}^{2}$ using $50 \times 50$ pixels $(1.5 \times 1.5 \mathrm{~km})$ grid.

contrasting values. Smaller grids $(2.3 \times 2.3$ and $1.5 \times$ $1.5 \mathrm{~km})$ were applied to a portion of the studied area (Fig. 7). With the $2.3 \times 2.3 \mathrm{~km}$ grid, the determination of maxima was possible, but cells with zero values were present over large portions of the represented area. This effect was stronger for the $1.5 \times$ $1.5 \mathrm{~km}$ grid.

\section{Conclusions}

Satellite lineaments are morphological features, usually related with fractures at a scale ranging from hundreds of metres to tens of kilometres. The spatial variation of density of lineaments can be calculated by the program LINDENS, presented here. This program generates a grid that divides the area under consideration into square cells, and calculates, for each cell, the lengths of the lineaments contained in the cell. The cell size is determined taking into consideration the distance between neighbouring lineaments. In this work, the distance between lineaments was calculated by means of the Delauney triangulation. The best-fit cell size was approximately the $P_{95}$ of the lineament distance. For larger grids, variations in density were not significant. For smaller cell sizes, artifacts as barren cells without a geological meaning may appear throughout the net.

\section{Acknowledgements}

The authors are very grateful to María José Marín and María Pilar Sancho, from the Centro de Tratamiento Digital de Imágenes of the Universidad de Zaragoza, who developed the automatic exploration 


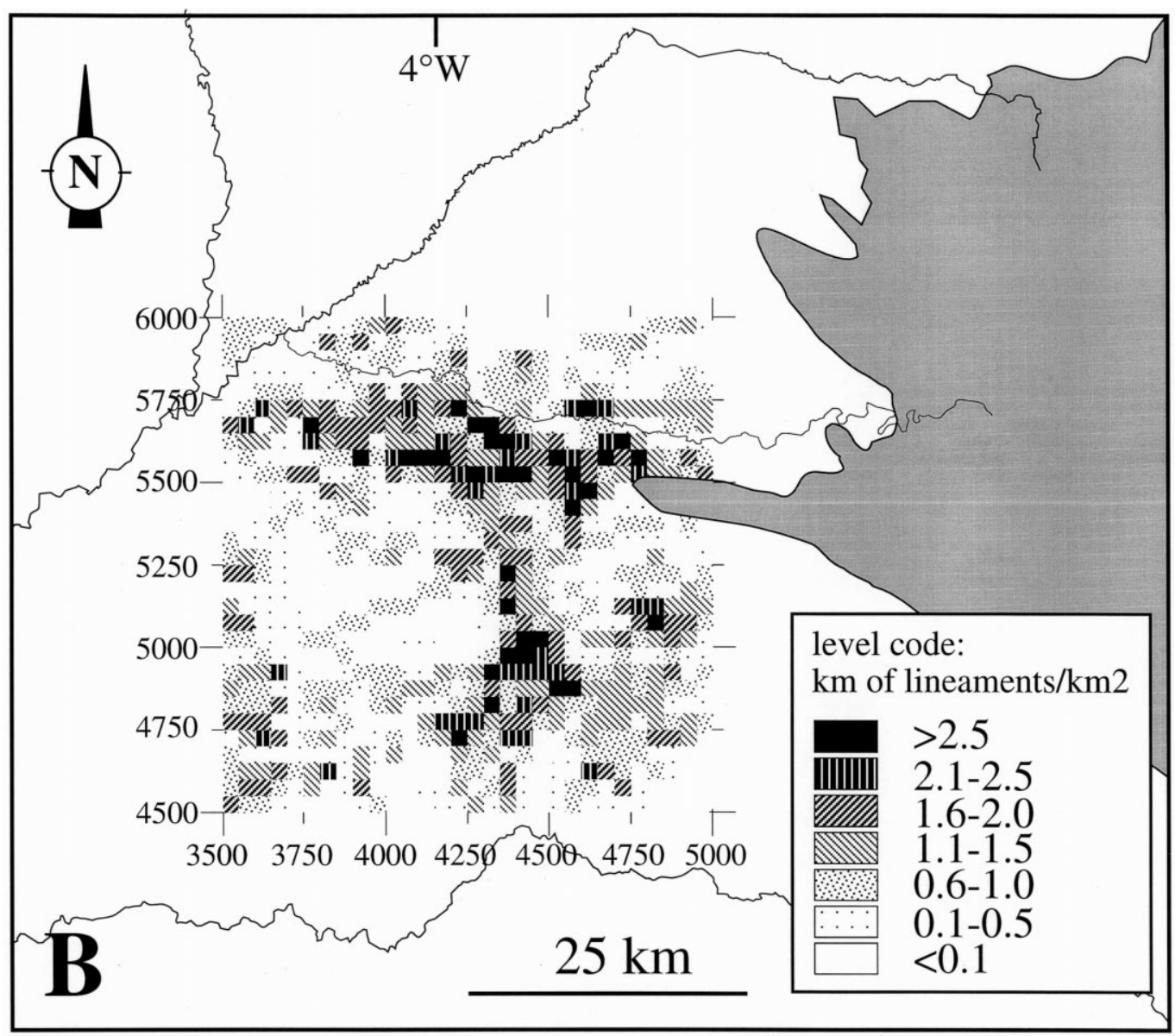

Fig. 7 (continued)

program. This work was supported by projects PB97-0997 of the Dirección General de Enseñanza Superior (Spain) and 221-98 of the Universidad de Zaragoza.

\section{References}

Arlegui, A.L., Soriano, M.A., 1996. Lineamientos y su influencia en los modelados del centro de la cuenca del Ebro (Lineaments and their influence in landscapes of the Central Ebro Basin). Cuadernos Laboratorio Xeolóxico de Laxe 21, 11-21.

Arlegui, A.L., Soriano, M.A., 1998. Characterizing lineaments from satellite images and field studies in the central Ebro basin (NE Spain). International Journal of Remote Sensing 19 (16), 3169-3185.

Chukwu, I.M., Norwan, J.W., 1977. Mineralized crustal failures shown on satellite imagery of Nigeria. Transactions of the Institution of Mining and Metallurgy, B 86, 55-57.
Cortés, A.L., Maestro, A., Soriano, M.A., Casas, A.M., 1998. Lineaments and fracturing in the Neogene rocks of the Almazán Basin, northern Spain. Geological Magazine 135 (2), 255-268.

Drury, S.A., Berhe, S.M., 1993. Accretion tectonics in northern Eritrea revealed by remotely sensed imagery. Geological Magazine 130, 177-190.

Heddi, M., Eastaff, D., 1995. Application of remote sensing to tectonics: case studies in the Guadix-Baza basin (southern Spain). In: Proceedings of the 21st Annual Conference of the Remote Sensing Society, pp. 841848.

Jutz, S.L., Chorowicz, J., 1993. Geological mapping and detection of oblique extensional structures in the Kenyan Rift Valley with a SPOT/LANDSAT-TM data merge. International Journal of Remote Sensing 14, $1677-1688$

Nash, C.R., Rankin, L.R., Leeming, P.M., Harris, L.B., 1996. Delineation of lithostructural domains in northern Orissa (India) from Landsat Thematic Mapper imagery. Tectonophysics 260, 245-257. 
Preparata, F.P., Shamos, M.I., 1985. Computational Geometry - An Introduction. Springer-Verlag, New York, $390 \mathrm{pp}$.

Sabins Jr, F.F., 1987. Remote Sensing. Principles and Interpretation. W. H. Freeman and Co, New York, 449 pp. Sanderson, D.J., Chinn, C., 1989. Analysis of Landsat lineaments: an example applied to the structural control of mineralization at la Codosera, Extremadura, Spain. In:
Acta III Reunión Científica del Grupo de Trabajo en Teledetección, Madrid, pp. 133-149.

Scanvic, J.-Y., 1975. Apport de l'imagerie spatiale multispectrale a la comprehension tectonique du Massif Central français et de son environnement sédimentaire. Bulletin du Bureau de Recherches Géologiques et Minières, Section 2: Géologie Appliquée, Chronique des Mines 4, 313-319. 